\title{
Kitekintés
}

GIMES JÚLIA GONDOZÁSÁBAN

\section{HATÉKONYABB SZÉN-DIOXID-MEGKÖTÉS}

A légkör magas és egyre gyorsabban növekvő szén-dioxid-koncentrációja a legsúlyosabb környezeti probléma a Földön, így a szén-dioxiddal kapcsolatos kutatások mindenütt kiemelkedő figyelmet kapnak. Különösen fontos eredménynek tủnik japán kutatók most közölt eredménye; olyan szén-dioxid elválasztási-megkötési módszert fejlesztettek ki, amelynek energiaigénye az eddig ismertekének kevesebb mint harmada.

A hidrogén sztripping regenerációs technológiának elnevezett eljárás szén-dioxid-tonnánként 1 gigajoule energiát igényel, a ma használtak 3-4 gigajoule-jával szemben. A folyamathoz szükséges hidrogént megújuló forrásból származó elektromos energiával állítják elő.

Az elnyeletőket a nagy szén-dioxid-kibocsátók, például hőerőmüvek kimenő füstgázaira telepítik, amelyeknek magas a szén-dioxid-koncentrációjuk.

Machida, H. - Esaki, T. - Yamaguchi, T. et al.: Energy-Saving $\mathrm{CO}_{2}$ Capture by $\mathrm{H}_{2}$ Gas Stripping for Integrating $\mathrm{CO}_{2}$ Separation and Conversion Processes. ACS Sustainable Chemstry and Engineering, 2020. 8, 8732-8740. DOI: 10.1021/acssuschemeng.0c02459

\section{GÉNTERÁPIÁVAL A PARKINSON-KÓR ELLEN}

Génterápiás eljárással gyógyítottak meg Parkinson-kórban szenvedő egereket a University of California San Diego kutatói.

Xiang-Dong Fu és munkatársai in vitro körülmények között felfedezték, hogy ha a neuronokat segítő idegrendszeri támasztósejtek egyik típusában, az ún. asztrocitákban megakadályozzák egy bizonyos fehérje termelődését, az asztrociták neuronokká alakulnak. (A fehérjét PTB-nek hívják, és fontos szereplöje a riboszóma nevü sejtszervecskén zajló fehérjeszintézisnek.)

Ennek a felismerésnek a birtokában olyan génterápiás rendszert konstruáltak, amellyel egerek agyában is el tudták hallgattatni a PTB szintézisét irányító gént. A gén kikapcsolása egy mesterséges DNS-darabkával történt, amely megakadályozza, hogy a PTB-molekula felépítéséhez szükséges örökletes információ érvényesülni tudjon. A megtévesztő DNS-szakaszt vírusdarabka juttatja be a sejtbe. 
Az eljárást mérgező anyaggal Parkinson-kórossá tett egereken próbálták ki. A kutatók a génterápiás rendszert közvetlenül a középagyba juttatták, abba az agyi régióba, amelyben Parkinson-kór esetén a dopamintermelő sejtek elpusztulnak, mozgási és egyéb tüneteket okozva ezzel. A kontrollcsoport tagjai azonban csak „üres” vírusdarabkát kaptak.

A terápia meglepően sikeresnek bizonyult. A valóban kezelt állatokban a megfelelő agyterületen az asztrociták dopamintermelő idegsejtekké alakultak, és az egerek parkinsonos tünetei eltüntek. Fu hangsúlyozza, hogy az állatokon végzett kísérletek sikeressége nem jelenti azt, hogy módszerük emberi betegség esetén is alkalmazható lesz, de minél előbb szeretnék megteremteni az új eljárás embereken történő kipróbálásának lehetőségeit.

A Parkinson-kór gyógyíthatatlan betegség. Kezelése, mely a dopamin lebomlását akadályozó vagy pótlását biztosító gyógyszerek alkalmazását jelenti, nem képes megállítani a sejtek pusztulását, így a betegség elörehaladását. Az új módszer új sejtekkel pótolná az elhaltakat. Természetesen az emberi tesztelésig nagyon sok kérdésre kell még válaszolni, egyebek között arra, hogy hogyan lehet szabályozni az újonnan kialakult idegsejtek mennyiségét, és garantálni, hogy biztosan ne következzen be kóros sejtburjánzás.

Qian, H. - Kang, X. - Hu, J. et al.: Reversing a Model of Parkinson's Disease with in situ Converted Nigral Neurons. Nature, 2020. 582, 7813, 550-556. DOI: 10.1038/s41586020-2388-4, https://www.nature.com/articles/s41586-020-2388-4

\section{REJTŐZKÖDŐ ANTIBIOTIKUMOK ELŐCSALOGATÁSA}

Baktériumokat szeretnének rávenni új antibiotikumok termelésére amerikai kutatók (University of Illinois).

A baktériumok akkor termelnek antibiotikumot, azaz számukra más mikroorganizmusok ellen védelmet nyújtó anyagot, amikor veszélyben vannak. Ha a baktériumsejtet káros hatás éri, hormonszerü anyagok keletkeznek, és azok kapcsolják be az antibiotikumtermelést. Laboratóriumi körülmények között a baktériumok jól érzik magukat, ezért feltételezhető, hogy valójában többféle antibiotikum termelésére képesek, mint ahányfélét hajlandók gyártani a kutatóknak. Az antibiotikum termelését hormonszerü anyagok szabályozzák, ezeknek a szintézisét indítja el a baktériumsejtet érő stressz.

Satish Nair és munkatársai az actinomycint és a streptomycint termelő baktériumcsalád (aktinobaktérium) avenolid nevű hormonját vizsgálták, amely egy talajbaktériumban az avermektin nevü féregellenes szer termelését szabályozza. A hormon a megfelelő receptorához kötődve kapcsolja ki azt a gátlást, amely az avermektin termelődését normális körülmények között megakadályozza. 
A kutatók röntgen krisztallográfiával felderítették a receptorhoz kötődés térbeli folyamatait, és szisztematikus vizsgálatokkal kiderítették, hogy a baktériumcsalád további kilencven tagja rendelkezik ilyen receptorral. Ez azt jelzi, hogy ezek a mikrobák is termelnek valamilyen más organizmus ellen ható anyagot, amelynek termelődését ugyancsak az avenolid hormon szabályozza.

Nairék most azt tervezik, hogy ezekből a baktériumokból tenyészeteket készítenek, és megnézik, mi történik, ha avenolidot kapnak. Azt remélik, hogy ennek hatására a baktériumok nem titkolóznak tovább, és előrukkolnak valami olyan, eddig ismeretlen antibiotikummal, amely az emberi gyógyászatban is használható lesz.

Kapoor, I. - Olivares, P. - Nair, S. K.: Biochemical Basis for the Regulation of Biosynthesis of Antiparasitics by Bacterial Hormones. eLife, 2020. 9, DOI: 10.7554/eLife.57824

\section{APASÁGI TESZT}

Pár perces szerepjátékban való viselkedésből elég pontosan lehet következtetni arra, az első gyermekük születésére készülő apák hogyan gondoskodnak majd gyermekükről - némileg leegyszerüsítve ez a megállapítása annak a kutatásnak, amelyben amerikai pszichológusok 182 fiatalember apává válását követték nyomon. A kutatásban részt vevők az első feladatot párjuk terhességének utolsó harmadában kapták: képzeljék el, hogy a kezükbe adott játékbaba a saját gyermekük. A „babázásról” videófelvételek készültek, amelyeket egyfajta pontrendszer szerint értékeltek, például olyan jeleket figyelve, hogy mennyit mosolyog, beszél vagy gügyög az apajelölt, mi mindent tesz, hogy a baba jól érezze magát.

A valódi gyermekek megszületése után ugyanezen apukákat egy másik pontrendszer szerint egy másik értékelő csoport is felmérte, miközben játszottak, vagy kirakós játékokat mutattak a gyermeküknek. Ök számszerüsítették a szülői odafigyelést, a pozitív hozzáállást, a szülöi gondoskodást.

Az eredmények meggyőző korrelációt mutattak a kétféle teszt között; a játékbabával való apáskodás képessége mintegy elöre jelezte, hogy mi várható a kispapáktól. A kutatók szerint azonban a szülői gondoskodást lehet tanulni, fejleszteni, és ebben látják munkájuk fő eredményét. Azokat a szülőket, akik még nem elég „gyermekérettek”, fel lehet készíteni a feladatra.

Altenburger, L. E. - Schoppe-Sullivan, S. J.: New Fathers' Parenting Quality: Personal, Contextual, and Child Precursors. Journal of Family Psychology, Advance online publication. DOI: 10.1037/fam0000753 


\section{EGYMÁS ÁLMÁT ŐRIZVE}

Jobb együtt aludni, mint külön, legalábbis a párban élőknek - ezt állapították meg német, dán és amerikai alváskutatók tizenkét fiatal, heteroszexuális pár komplex alvásminőségének vizsgálata során. A párokat alvás közben úgynevezett poliszomnográffal figyelték. A vizsgálatokat elvégezték úgy is, hogy egy ágyban és úgy is, hogy külön aludtak.

A berendezés képes nagyon sok paramétert egyidejűleg regisztrálni, egyebek között az agyhullámokat, a mozgást, légzést, szívmüködést, az izmok tenzióját.

Amikor a párok együtt aludtak, az úgynevezett REM-fázisok hosszabbak voltak, és ritkábban szakadtak meg. Az alvásnak ez az intenzív, álmokkal is kísért szakasza nagyon fontos, többek közt az érzelmek szabályzásával, a memória megerősítésével, a szociális kapcsolatokban való viselkedéssel és a kreativitással is kapcsolatba hozzák.

Az együtt alvás során a párok alvásszinkronizációját is megfigyelték, és ennek mértéke pozitív korrelációt mutatott a kapcsolat erősségével. A kapcsolat minőségét, kérdőíves válaszaik segítségével, maguk a résztvevők értékelték.

Drews, H. J. - Wallot, S. - Brysch, P. et al.: Bed-Sharing in Couples Is Associated With Increased and Stabilized REM Sleep and Sleep-Stage Synchronization. Frontiers in Psychiatry, 2020. 11, 583. DOI: 10.3389/fpsyt.2020.00583, https://www.frontiersin. org/articles/10.3389/fpsyt.2020.00583/full

\section{AUTOMATIZÁLT DRÓNOK A MALÁRIA ELLENI KÜZDELEMBEN}

A szúnyogok által terjesztett kórképek - malária, dengue-láz, sárgaláz, Zika a világon a fertőző betegségek 17 százalékát jelentik. Évente kb. egymillió új megbetegedés történik. A szúnyogok számának drasztikus csökkentésére a WHO 2017-ben indult és 2030-ig tartó globális programja alternatív megoldásokat keres a rovarirtó szerekkel szemben. A rovarirtó szerek használata ugyanis káros az ökoszisztémára, káros a környezetre, ráadásul a kialakuló rezisztencia miatt egyes szerek hatékonysága is folyamatosan csökken.

Régi elképzelés, hogy az erősen szúnyogos területeken terméketlen szúnyogok elterjesztésével kellene a szúnyogpopuláció számát csökkenteni. Most egy nemzetközi kutatócsoport olyan teljesen automatizált drónos rendszert fejlesztett ki, amely homogén eloszlásban képes az adott területre terméketlen hím szúnyogokat juttatni. Ráadásul ezt úgy, hogy a rovar sérülékeny lábai és szárnyai épek maradnak. A dobozos adagolórendszerrel, egy alkalommal ötvenezer szúnyogot lehet a levegöbe juttatni. 
A rendszert egy éven át Brazíliában és Kínában tesztelték. A vizsgálatok során azt is kimutatták, hogy a kibocsátott szúnyogok életerősek, és tudnak párosodni.

A terméketlen szúnyogok tömeges elterjesztésének célja természetesen a populáció létszámának csökkentése, hiszen ezeknek a hímeknek nem lehetnek utódaik.

Bouyer, J. - Culbert, N. J. - Dicko H. et al.: Field Performance of Sterile Male Mosquitoes Released from an Uncrewed Aerial Vehicle. Science Robotics, 15 Jun 2020. 5, 43, eaba6251. DOI: 10.1126/scirobotics.aba6251 